\title{
Social Media Use in European Hotels: Benefits and Main Challenges
}

El uso de herramientas Social Media en hoteles europeos: Principales retos, oportunidades y dificultades

\section{Aurora Garrido-Moreno}

Universidad de Málaga, Facultad de Estudios Sociales y del Trabajo, Campus de Teatinos (Ampliación), 29071 Málaga, Spain, agarridom@uma.es

\section{Nigel Lockett}

University of Leeds, 23 Lyddon Terrace, LS2 9JT Leeds, UK, n.lockett@leeds.ac.uk

\begin{abstract}
The advent of Social Media tools has been one of the most relevant technological innovations in recent years and has strongly impacted the tourism industry. Despite the numerous benefits that Social Media can offer to hotels, transforming the way they relate to customers and opening a vast array of new possibilities, its implementation implies also numerous challenges. Considering that the use of Social Media is becoming increasingly popular, it seems to be critical to understand how hotels can use them strategically to reinvent customer relationships. This study explores the topic following a mixed methodology, combining both quantitative and qualitative data from a European sample of 312 hotels. Results suggest that review sites and social networks were the most used tools. The main advantages and disadvantages of its use were identified and widely discussed.
\end{abstract}

Keywords: Social Media tools, hotel sector, social networks, Social Media adoption, review sites.

\section{Resumen}

El desarrollo y popularización de herramientas de Social Media ha constituido una de las innovaciones más relevantes en los últimos años y ha ejercido un tremendo impacto en la industria hotelera. A pesar de los múltiples beneficios que el uso de dichas herramientas puede ofrecer a los hoteles, transformando la forma en que se relacionan con sus clientes y abriendo una multitud de nuevas posibilidades, su implementación implica también numerosas dificultades y desafíos. Teniendo en cuenta que el uso de Social Media es cada vez más popular, resulta crítico conocer y comprender cómo los hoteles pueden utilizar dichas herramientas de manera estratégica para reinventar sus relaciones con clientes. El presente estudio analiza la temática siguiendo una metodología mixta, combinando datos de carácter cuantitativos y cualitativo obtenidos de una muestra de 312 hoteles europeos. Los resultados obtenidos indican que tanto las plataformas que incluyen comentarios y opiniones de clientes como las redes sociales mostraron ser las herramientas más utilizadas en los hoteles analizados. Asimismo, las principales ventajas y dificultades que surgieron con su uso fueron analizadas y ampliamente discutidas.

Palavras-chave: Herramientas Social Media, sector hotelero, redes sociales, adopción de Social Media, sitios de revisión.

\section{Introduction}

Information Technologies have transformed tourism globally, changing radically the way that business are conducted in the marketplace, as well as how consumers interact with organizations (Buhalis \& Law, 2008). The emergence of Social Media (SM) has implied drastic changes by turning the Internet into an immense space of social networking and collaboration of users, and recent studies describe the adoption and potential of social media in tourism as enormous (Neuhofer, Buhalis \& Ladkin, 2012).

In the last decade, SM has emerged as a real game changer, putting the customer at the center of the organization (Smith $\&$ Zook, 2011). The use of these technologies represents a revolutionary new trend for companies (Kaplan \& Haenlein, 2010), and is even assumed as the biggest change since the industrial revolution. Hotel worldwide are realizing its potential and are using different tools (such as Facebook, Twitter, Youtube) to engage customers in active conversations and reinvent customer experience (Baird \& Parasnis, 2010). SM use can provide multiple benefits for hotel companies: improved brand perception, increased e-word-of-mouth, improved customer knowledge and valuable feedback for new product development (Sigala, 2011). These tools provide a convenient way for engaging customers in new service development and improve the image of the brand (EscobarRodríguez \& Carvajal-Trujillo, 2013; Hsu, 2012; Sigala, 2012). Hotels are beginning to take advantage of SM opportunities to increase visibility, evaluate customer suggestion and build trust and credibility (Haro de Rosario, Gálvez-Rodríguez \& Caba-Pérez, 2013). However, SM implementation involves also an enormous challenge and managers need to know how to effectively integrate these tools to leverage all its potential (Noone, McGuire \& Rohlfs, 2011). In fact, hotels all over the world are employing Social Media to some extent, but a lot of these initiatives are failing, because they do not attract customer interest nor create business value (Bradley \& McDonald, 2011).

Due to the novelty of the concept, there is an urgency to further investigate how SM tools are being implemented in a hotel context. In order to fill this gap, this study poses three main objectives:

(1) To provide empirical evidence of the different level of use of the main SM tools.

(2) To examine if there were some characteristics of the hotels which were associated with a higher level of SM adoption. 
(3) To explore the main advantages and to emphasize the different challenges which arise when implementing these initiatives.

The paper is organized as follows. After a literature review, the methodology and main results of the empirical study are described. The conclusions, along with some future research lines close the paper.

\section{Literature review}

SM refers to a set of online tools that supports social interaction between users, facilitating the creation and sharing of knowledge, and transforming monologue (company to customer) into dialog (Hansen, Shneiderman \& Smith, 2011). One of the most accepted definitions of SM is the one proposed by Kaplan \& Haenlein, (2010, p. 61), which considers it as a group of Internet-based applications that build on the ideological and technological foundations of Web 2.0, and that allow the creation and exchange of User Generated Content. Web 2.0 refers to the technical infrastructure that enables the social phenomenon of collective media and includes a series of technological innovations in terms of both hardware and software that facilitate inexpensive content creation, interaction, collaboration, and community on the World Wide Web (Berthon, Pitt, Plangger \& Shapiro, 2012). There are different types of Social Media tools such as instant messaging, blogs, microblogs, social networking sites, wikis, photo and video sharing sites, review sites, tagging and news feed (Hansen et al., 2011; Berthon et al., 2012, Munar \& Jacobsen, 2014) (see Table 1 for a brief description of them).

Table 1 - Types of Social Media tools

\begin{tabular}{|c|c|c|}
\hline Social Media tool & Description & Examples \\
\hline Tagging & $\begin{array}{l}\text { Social bookmarking sites that enable users to share, } \\
\text { organize and search bookmarks of web resources }\end{array}$ & Delicious, Diigo \\
\hline Discussion forums & $\begin{array}{l}\text { Online discussion sites where users can share information } \\
\text { and opinions, in the form of posted messages }\end{array}$ & $\begin{array}{l}\text { Google groups, Yahoo! Groups, } \\
\text { Yahoo! Answers }\end{array}$ \\
\hline News feed & $\begin{array}{l}\text { Data format used for providing users with frequently } \\
\text { updated content }\end{array}$ & RSS \\
\hline Microblogging & $\begin{array}{l}\text { Web platforms where users can send and read very short } \\
\text { messages, usually restricted by the number of characters } \\
\text { (e.g., Twitter allows } 140 \text { characters per message) }\end{array}$ & Twitter, Tumblr, Buzz \\
\hline Blogging & $\begin{array}{l}\text { Special form of web page publication, consisting on a series } \\
\text { of text messages or "posts" displayed in reverse } \\
\text { chronological order }\end{array}$ & $\begin{array}{l}\text { LiveJournal, Blogger, Wordpress, } \\
\text { Travelblog }\end{array}$ \\
\hline Instant messaging & $\begin{array}{l}\text { Specific systems that enable synchronous conversations } \\
\text { between two or more users }\end{array}$ & MSN Messenger, Google Talk \\
\hline Photo-sharing & $\begin{array}{l}\text { Online platforms where users can store and share digital } \\
\text { photographs }\end{array}$ & $\begin{array}{l}\text { Flickr, Picasa, Instagram, } \\
\text { Pinterest }\end{array}$ \\
\hline Video-sharing & $\begin{array}{l}\text { Online platforms designed to allow individuals to freely } \\
\text { upload and share video content }\end{array}$ & Youtube, Vimeo, Vine \\
\hline $\begin{array}{l}\text { Social Networking } \\
\text { sites }\end{array}$ & $\begin{array}{l}\text { Online platforms on which users can find and add friends } \\
\text { and contacts, send messages to them, and update personal } \\
\text { profiles. Social networking services allow people to share } \\
\text { information with their self-identified friends or followers }\end{array}$ & $\begin{array}{l}\text { Facebook, MySpace, Tagged, } \\
\text { Google+, BlackPlanet, Tuenti, } \\
\text { Hi5, Linkedln, Xing }\end{array}$ \\
\hline Review sites & $\begin{array}{l}\text { Websites where users can post reviews and comments } \\
\text { about businesses, products, or services }\end{array}$ & $\begin{array}{l}\text { (Tourism) Trip Advisor, Lonely } \\
\text { Planet, Booking.com }\end{array}$ \\
\hline
\end{tabular}

Source: Self-elaborated from Hansen et al. (2011), Munar \& Jacobsen (2014), IAB Spain (2014).

SM tools are considered as one of the most appropriate tools for hotels to communicate with their users and to develop effective relationships with them (Escobar-Rodríguez \& Carvajal-Trujillo, 2013). Social networks (e.g., Facebook) and microblogging sites (e.g., Twitter) are becoming increasingly popular and have substantially impacted the whole travel industry. The use of Facebook allows hotels to gain more knowledge of their customers, interact with them fluidly and inform them persuasively (Hsu, 2012). In addition, in this sector, the use of review sites such as Trip Advisor is becoming crucial as it is said to influence more than US\$10 billion in online travel purchases every year (Ye, Law, Gu \& Chen, 2011).

TripAdvisor-branded sites comprise the largest travel community in the world, reaching nearly 260 million unique monthly visitors, and more than 150 million reviews and opinions covering more than 4 million accommodations, restaurants, and attractions (Google, 2014). The site has become one of the world leaders in travel information (the sites operate in 42 countries worldwide), containing more user-generated content than any other travel website and bringing people together in discussion forums. The system provides users with independent travel reviews and comments written from other members and expert advisors and provides a powerful platform for interaction and sharing experiences (Cabiddu, De Carlo \& Piccoli, 2014). In fact, on a recent survey conducted about the impact of customer reviews with a sample of more than 10.000 hoteliers and 50.000 Tripadvisords users, it was observed that $89 \%$ of global travellers considered that reviews were influential when choosing their accommodation (TripBarometer, 2014).

Regarding the main benefits that SM can bring to hotels, authors highlight that these tools facilitates the identification of customer needs, the level of customer satisfaction and the creation of a community of followers (Haro de Rosario et al., 2013). Additionally, they tools support the democratization of knowledge and information, transforming individuals from 
mere content consumers into content producers and building emotional bonds with them (Berthon et al., 2012; Kaplan \& Haenlein, 2010). Engaged customers become partners who collaborate with sellers in the value adding process to better satisfy their needs as well as the needs of other customers (Sashi, 2012). This active dialogue can notably improve customer knowledge management, allowing the understanding of customer needs and facilitating modifications to existing products or the development of new products to better satisfy their needs (Sashi, 2012).

Focusing on the state of SM research in a hotel context, some authors considered that research into the business use of SM is still in an embryonic state (Michaelidou, Siamagka \& Christodoulides, 2011). However, recently, there has been a notably increase of research addressing the topic. The proliferation of online reviews and the importance of User Generated Content has been widely analysed in different studies. Silveira-Chaves et al. (2012) and Park and Allen (2013) focused on how hotels responded to online reviews in sites like Trip Advisor, using these sites as one relevant mechanism to identify and solve customer problems. Blal and Sturman (2014), based on a sample of UK hotels, demonstrated the relative magnitude of the effects of online ratings, and observed that ratings had a greater effect on upper-tier hotels, while volume of reviews drove the lower-tier hotels' results. Those findings were confirmed in both independent hotels and those integrated in chains. Additionally, Sigala (2012) examined the implications of Web 2.0 for enhancing customer involvement in new service development in the Greek tourism industry; and Ye et al. (2011) empirically confirmed that online user-generated reviews had a significant impact on online sales and business performance.

On the other hand, specific research about the hotel's use of SM from an internal or organizational perspective remains scarce. In this vein, Haro de Rosario et al., (2013) analysed the use of Web 2.0 tools and social communication media of the world's 50 largest hotel chains, and detected that the size and age of the hotel chain influence the increased use of SM tools. Chan and Guillet (2011) investigated the extent to which SM was utilized in the Hong Kong hotel industry, and observed that Facebook and Twitter were the most used tools, and that hotels generally had a poor performance in using social media to learn about customers. Additionally, Jung, Ineson and Green (2013) identified and evaluate the role and the existing and potential use of online social networking as a marketing tool in the luxury four- and five-star hotel market in UK. Hotel marketers in this country claimed to utilise social networking from a relational perspective as a communication facilitator, and social networks were mostly exploited for service recovery and implementing corrective actions in response to negative user comments. However, they also recognised that that they were not taking advantage of the full potential of these tools in terms of marketing opportunities. Finally, Escobar-Rodríguez and Carvajal-Trujillo (2013) examined the topic in a sample of 110 Spanish hotel chains and explored the relationship between the size of the hotel and their website strategy. It was found that a majority of the hotel chains showed a high score in SM presence (use of different SM tools), and displayed a generalized use of Web 2.0 platforms to develop and exploit interactivity with customers. It was observed also that larger hotel chains showed a greater presence on SM platforms.

As it can be observed, most of the mentioned studies focused on one specific SM tool (Review sites, social networks) but there is a lack of studies examining Social Media adoption strategically, following an integrative approach, or drawing on an international sample. In fact, Line and Runyan (2012) recently reviewed the hospitality sector articles published in top journals and concluded that further marketing studies are needed on SM in the tourism sector. In the same vein, different authors stressed that there is an overwhelming requirement for academic exploration into how hotels can exploit this new marketing tool, as well as specialized industrybased research concerning their effectiveness and utilization (Buhalis \& Law, 2008; Jung et al., 2013).

SM use has become a golden opportunity for hotels nowadays and it involves a new way of running the business (Smith \& Zook, 2011). Consequently, in a hotel context, it is of critical importance understanding how this new channel works for formulating efficient strategies to fully exploit its potential (Garín-Muñoz \& Pérez-Amaral, 2011). To shed light on the topic, the present paper contributes to the limited research into Social Media adoption in the hotel sector, examining the most used tools and placing the focus on the main advantages and challenges that arise when implementing them.

\section{Methodology}

To provide empirical evidence on the topic, an exploratory study was conducted with data from Spain and UK hotels. European hotels were targeted in this study for different reasons. Firstly, Europe is a major tourism destination, accounting for $52 \%$ of all international arrivals worldwide (World Tourism Organization, 2013). We focused particularly on hotels from Spain and UK, since both countries were considered World's Top Tourism Destinations and are included in the top 10 ranking by international tourism receipts (occupying the fourth and eighth position respectively) (World Tourism Organization, 2013). In addition, we found previous studies conducted in different sectors that also included data from companies of both countries (Llonch, Eusebio \& Ambler, 2002; Mena, Adenso-Díaz \& Yurt, 2011).

Based on the literature review, a structured questionnaire was designed for hotel managers. To collect the information, we followed the key-informant methodology, choosing the hotel managers as informants. We decided to interview hotel general managers for a number of reasons: they are the most knowledgeable about the whole organization; they manage a great deal of information in all departments of the company; they constitute a valuable source for evaluating the different variables under study throughout the organization; and they are ultimately responsible for plotting the organization's direction and plans, as well as for guiding the actions carried out to achieve them (Westphal \& Fredickson, 2001). 
The target population of the study consisted of hotels from 4-5 stars located both in Spain and in UK and their contact data were gathered from different databases. In Spain, we selected data from a database from Turespaña (Spain's Ministry of Tourism) and in UK, we used a private database provided by a UK-based company, Simply Data. The questionnaire was sent by e-mail and the final sample was composed by 312 hotels from both countries.

To verify that the sample obtained was representative of the population, non-response bias was analyzed. Responding and non-responding hotels were compared in terms of firm size, category and property regime and no significant differences between the two groups were found, so non-response bias did not affect the collected data.

Regarding the characteristics of the respondents, focusing on the size of the hotels (measured in number of employees), most of them were small hotels: $82.7 \%$ had less than 50 employees, and 17.3 were medium and big hotels. The majority of the sample had $3(47.4 \%)$ and 4 stars (39.1\%), and respect to their ownership structure, most of them were independent hotels (66\%) while the rest were integrated in chains.

Additionally, 10 semi-structured interviews were conducted with hotel managers ( 5 in each country) in order to provide some additional insights into their use of SM tools. Semistructured interviews were employed, as they are particularly appropriate for an unexplored research topic, especially when dealing with confidential company information such as marketing strategies (Gilbert, Powell-Perry \& Widijoso, 1999). All interviewees provided informed consent. Confidentiality was granted to the informants, because it was considered necessary in order to achieve a higher level of critical evaluation of the involved organizations (Miller \& Glassner, 2004). The interviews ranged from 20-55 minutes, were recorded and later transcribed. The interview transcripts were analyzed by the standards set by Miller and Glassner (2004). Firstly, an analysis of the interviewees' responses was conducted to identify emerging themes related to SM adoption and use. Secondly, an in-depth narrative analysis was made by the two authors in order to compare and contrast the findings.

\section{Results and discussion}

The results and discussion were divided in two main sections. First, the quantitative analysis will be described, and then the results of the qualitative study will be discussed.

\subsection{Quantitative analysis}

In order to analyze the use of SM tools in the studied hotels, based on Sigala (2011) the following tools were included in the questionnaire: forums, blogs, microblogs (Twitter), social networking, video-sharing, photo-sharing, review sites, news feed, tagging and instant messaging. The different level of use of these tools in hotels for both countries is reflected in Figure 1.

Figure 1 - Use of Social Media tools

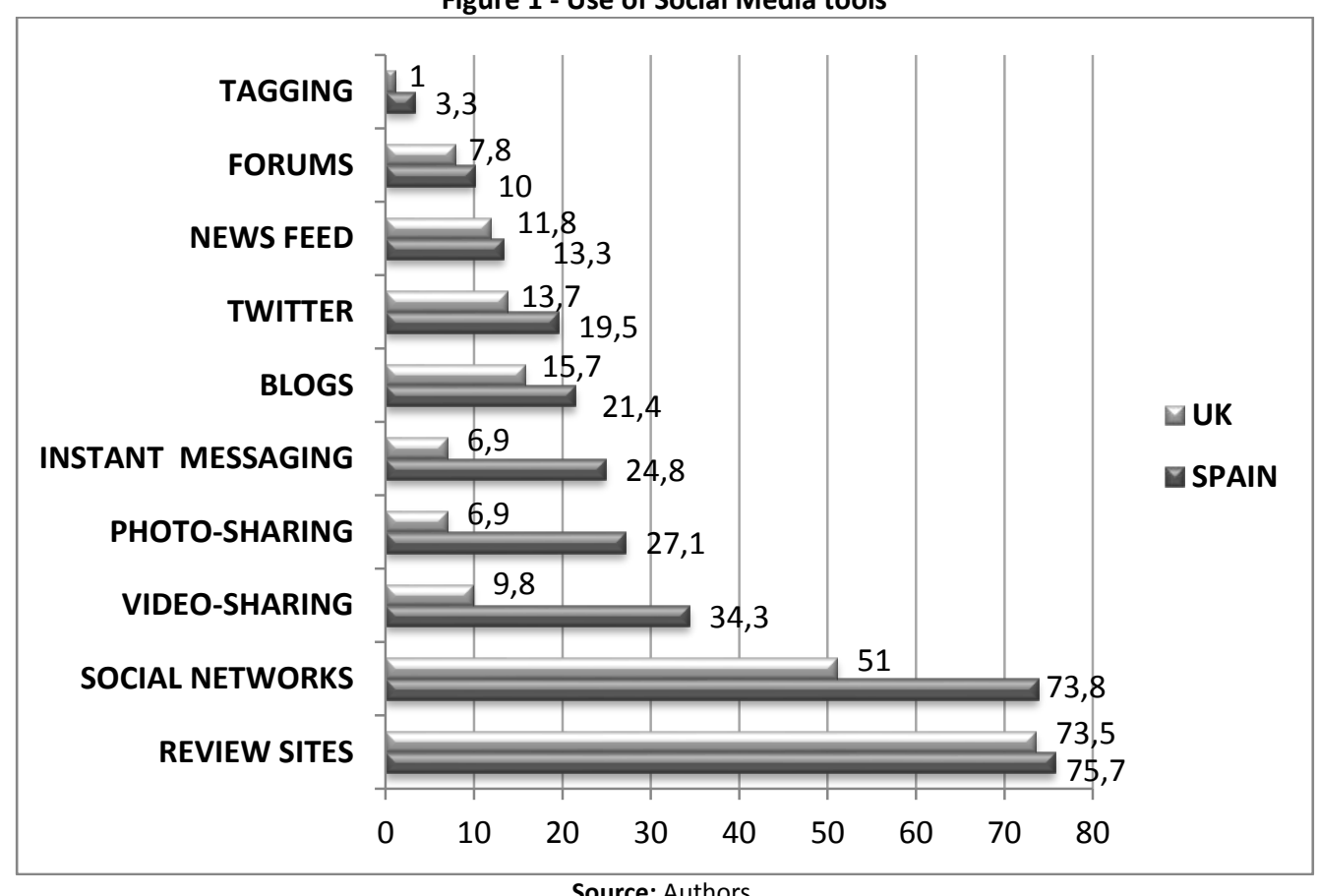

The most used tools in both countries were review sites (over $70 \%$ of hotels reported using TripAdvisor) and social networks. It was also noted that the use of some tools varied widely among hotels in Spain and the UK (See Figure 1).

To know if this difference was relevant and statistically significant, the Mann-Whitney $U$ test on difference between means was used, because data were non-normal. As the bilateral critical level was lower than 0.05 , it was accepted that the difference of means was statistically significant in the use of the following tools: social networks, video-sharing, photosharing and instant messaging. So, Spanish hotels showed a more intensive use of these four specific tools.

In order to examine if some characteristics of the hotel (ownership structure, category and size) were associated with 
a most intense use of Social Media tools, a correlation analysis was conducted using the Spearman coefficient. Spearman's rank correlation coefficient is a non-parametric measure of statistical dependence between two variables that can be applied to non-normal data.

Similarly to previous studies (Haro de Rosario et al., 2013), a summatory index was calculated to measure SM use (it ranged from 0 to 10 , including the use of the ten mentioned tools). Results of the analysis showed that ownership and hotel size were correlated with a higher use of SM (the significance of the coefficient was lower than 0.05). Consequently, larger hotels and those who were integrated in chains were more prone to use SM tools. It was also found that hotel category was not associated with SM use (See Table 2).

Table 2 - Correlation analysis

\begin{tabular}{|l|c|c|c|}
\hline \multicolumn{1}{|c|}{ Variables } & Spearman Coefficient & Significance & Effective correlation \\
\hline Social Media Index and ownership & 0.216 & 0.000 & Accepted \\
\hline $\begin{array}{l}\text { Social Media Index and category } \\
\text { (number of stars) }\end{array}$ & 0.107 & 0.072 & Rejected \\
\hline $\begin{array}{l}\text { Social Media Index and hotel size } \\
\text { (number of employees) }\end{array}$ & 0.183 & 0.001 & Accepted \\
\hline
\end{tabular}

These findings are consistent with the one of Orfila-Sintes, Crespí-Cladera and Martínez-Ros (2005) who, analyzing the implementation of technological innovations in a sample of Spanish hotels, observed that larger hotels were more innovative than small ones, and hotels belonging to a chain were much more inclined to introduce technological innovations than independent hotels. These authors also found no significant differences between the innovation percentages corresponding to 3,4 and 5 star hotels. In addition, Haro de Rosario et al., (2013) examining a sample a hotel chains, observed also that largest hotels were more interested in using these tools. Consequently, assuming SM adoption as a technological innovation, it can be asserted that large hotels and hotels integrated in chains seems to have more managerial resources and so were more prone to embark on this initiatives.

\subsection{Qualitative analysis}

To deepen on the use of Social Media tools in a qualitative way, 10 semi-structured interviews were conducted and the main advantages and challenges of its adoption were analysed. The main topics that arose in the interviews will be described.

\section{Advantages of SM adoption}

The vast majority of the interviewed managers were really positives about the benefits of adopting SM tools. The main advantages cited by hotels were improved image, customer proximity or the fact of capturing customer knowledge to keep innovating and better satisfy customer needs. Most of the managers emphasized that SM is a channel where they need to be nowadays: "Considering that one of our brand attributes are customer relations, if we were not able to develop a channel as Social Media we would have a problem", "That is a growing area, it certainly is a growing area", "We have to evolve based on how society evolves". In addition, being in these channels gives hotels an image of modernity and proximity to customers that helped them to connect with a young target audience: "It gives us a touch of modernity", "It is more of a community-based thing". In the same vein, EscobarRodríguez and Carvajal-Trujillo (2013) noted that for hotels, Social Media tools have become the most effective tools for communicating and interacting with user.
A positive attribute that the interviewees associated with the adoption of Social Media tools was that thanks to the effective dialogue they provide, hotels have improved customer relationships. Using these platforms, they gain rich information from customers which enable them to keep innovating. In this vein, one respondent commented that: "Social Media use generates a dynamic of innovation based on customers' views that is really important for us". "We go through guest feedback obtained in these channels and we discuss it. It is a new avenue and it is a free avenue that we can use". "Its use is proving very useful to capture information on guest preferences, and to plan actions and modify the product based on this information". "Social networks are nowadays, not only a means of communication with the customer but of dynamization of the demand, allowing you to obtain information for multiple things".

Our findings were consistent with previous studies. In this vein, Hsu (2012) and Jung et al. (2013) noted, one of the main advantages for hotels of using Social Media was the fact of gaining more knowledge of their customers, that allows them personalize their service and be able to enhance hotel guests' experience based on this knowledge.

Related to this advantage, using SM to acquire knowledge from customers, there is a specific SM tool that deserves a special attention: the use of Trip Advisor. All managers interviewed conceded a crucial importance to this review site, which collects customer feedback, because of the information that could be obtained from it. Trip Advisor is something which we keenly keep an eye on because that is all about customer feedback and experience and we go through that every week". "I believe this channel is strategic, because the reviews and opinions published in Trip Advisor are essential when a person decide to book a room". In this vein, online reputation was considered a fundamental aspect: "One of the fastest tools is word of mouth, and the negative opinions are the fastest and most damaging spread". Therefore, the management of complaints and negative feedback was highlighted by all managers as a crucial issue to take into account, because consumer perceptions and behavior were significantly affected by online review content (Park \& Allen, 2013). Consequently, most of the interviewed claimed to personally respond to complaints and claims, in order to mitigate their negative impact, and to show customers that there is interest from the 
hotel: "I am very concerned about what is being called online reputation, and I always answer the complaints because I think that is strategic, what is your image online, what was said of you, and how did you respond", "We do look at Trip Advisor a lot because there are obviously comments coming through to there. We normally look again at the analysis of these comments and respond to them - good or bad the manager will respond to any comment".

\section{Main challenges}

Regarding the main challenges cited by interviewed managers, they were related to the difficulty of measuring SM impact, the lack of initial knowledge on the topic, privacy concerns and the lack of a strategic focus when adopting these tools.

Most of the managers were concerned about the real impact of SM use on performance as they cannot find a direct ROI of it. Typical statements from respondents included: "Direct profitability is difficult to get from this channel. For me, the true $\mathrm{ROI}$ is richness in terms of feedback that can give you the customer, which is what will allow you to develop the product and implement various strategies that will have a real ROI. But to seek a direct ROI on a customer's view, it seems a bit risky", "I don't think it is bringing back enough reward", "In the end it is about generating impact, but the tool will require more time than the sale finally gives you". This challenge was also emphasized by previous research. Chan and Guillet (2011) concluded that it remains unknown whether Social Media could actually bring financial returns that justify the invested resources on it. Measuring productivity from Social Media tools seems difficult, thus most hotels are focused on receiving a "return on engagement" as opposed to a return on investment (Jung et al., 2013).

Other managers highlighted the lack of specific training on the subject as a real difficulty when starting to use these tools. As one respondent noted: "There is no training about the topic, no one has explained to us what to do, how and what the objectives are", "At first you know you have to be in these channels, but you're not quite sure why", "These things are so new that learning occurs through trial-and-error". In addition, the rapid evolution and penetration of these tools makes more complicated its use: "Social Media is very viral, everything runs very quickly and there may come a time when you lose all control", "So it just makes the world faster, the information faster coming through and we have probably got to be a little bit faster to respond to all of that". In this vein, the lack of education and/or training in the use of Social Media was previously highlighted as a relevant handicap in this sector, and some hotels were developing experimental approaches when adopting these tools (Jung et al., 2013).

Additionally, some managers showed privacy concerns when using these channels, and they were negative about the depersonalization of service that an excessive use of technology can cause or the fact that an overuse of these tools can lead the hotel to forget their core business: "We sell sleep, accommodation, we do not sell show", "Everyone has to focus on their business and do what he has to do, so we integrate in social networks only relevant information, but I think a hotel does not have to be announcing events all day, and I believe that the hotel need to keep privacy".

Finally, some managers noted that implementation challenges appear to be more strategic in nature: Why are we doing it rather how do we do it. Some interviewed admitted that they had embarked in the use of SM without integrating it in their global strategy or having set specific goals for it. In this vein, one respondent mentioned that strategic integration was one of the main challenges when implementing SM to improve customer relationships: "I think you have to define first the strategy: what you want to do with social networking, what is your intention: branding, customer service, use it as a sales channel", "The problem is that the role of Community Manager has been created as a concept, as the person exclusively in charge of social networks, but without there being aligned with business objectives". As Chan and Guillet (2011) highlighted, to ensure that the hotel is doing well when implementing SM, managers must clearly communicate its objectives and the way it should be used to other levels, and control systems need to be implemented. So it was observed that hotel managers should adopt a more strategic, knowledgeable and planned approach to Social Media exploitation (Sigala, 2012).

Based on the above discussion, a summary of the main findings of both the quantitative and qualitative analysis conducted is reflected in Figure 2.

Figure 2 - Summary of the main findings

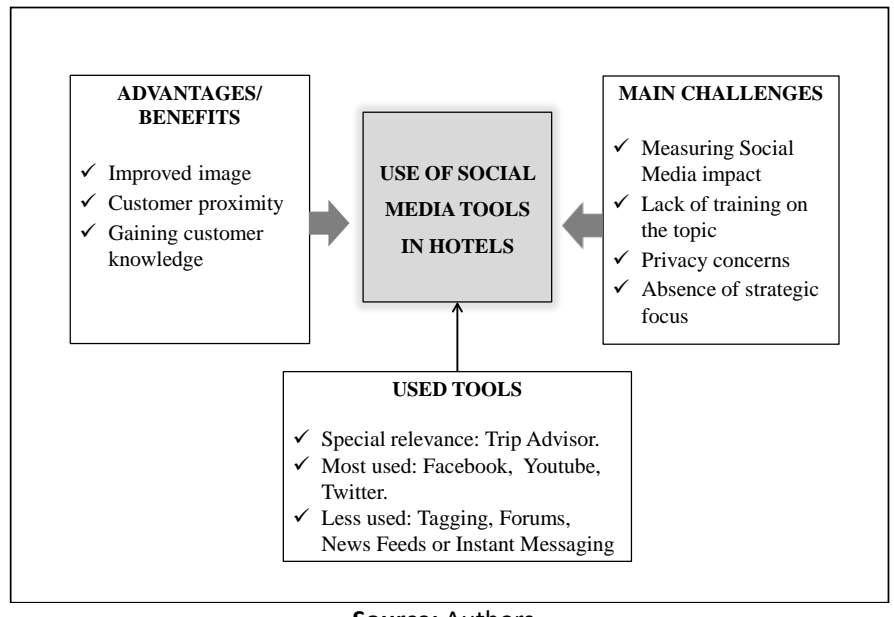

Source: Authors. 


\section{Conclusions, limitations and future research}

Social Media tools are here to stay and have configured a new landscape for hotel companies. Due to the relative novelty of the concept, its adoption and use poses a major challenge, and more research is needed to guide hotels to their effective implementation. This paper explores the adoption and use of different SM tools based on a sample of 320 hotels from Spain and UK, using a mixed methodology, and offers new insights on the topic.

Regarding the implementation and use of SM, it was observed that review sites and social networking appeared as the most used SM tools. Hoteliers actively managed TripAdvisor reviews and acknowledged having an active presence on social networks like Facebook. In addition, results confirmed that Spanish hotels made a more intensive use of social networks, video and photo-sharing and instant messaging than English hotels. Concerning the factors that can influence the use of SM in the hotel sector, it was found that ownership structure (integration in chains) and hotel size were positively related with a wider use of Social Media tools. Therefore, larger hotels and those integrated in chains were more prone to implement these technologies to better interact with customers.

Focusing on the most mentioned advantages of SM adoption, hoteliers stressed that these tools help them to better approach their customers, improving their image and giving them a touch of modernity. In addition, interviews confirmed that one of the most valued benefits of SM use was the fact of gaining customer knowledge to keep innovating and satisfying their needs properly. Hotels were taking advantage of these tools to observe consumer trends and collect valuable feedback to develop new products and personalize its service. In this vein, the most relevant tool for hotels, which was mentioned by all the interviewed managers, was the review site Trip Advisor. Managers recognized the importance of managing and responding customer reviews, because online reputation is critical nowadays. Consequently, they personally respond to complaints and utilize customer feedback as a base to improve their service.

Addressing the main challenges that emerged when implementing SM, the most cited issue was the difficulty of measuring its impact. Most managers considered that these tools did not have a direct ROI, but helped to gain customer knowledge and loyalty. So it can be considered that they do have a "return on engagement", as previous authors found (Jung et al., 2013). Other mentioned challenges were lack of specific training, privacy concerns and strategic integration. In this regard, hoteliers acknowledged the need to integrate their Social Media programs with the overall marketing strategy, defining an appropriate mix of channels and establishing clear objectives, responsibilities and measures to evaluate these initiatives.

It was observed also a slight difference in the level of advance and focus of SM use, between hotels from both countries. Spanish hotels proved to be more advanced, and some of the interviewed hotels were even integrating SM tools into their customer relationship strategy, creating a specific department for managing them and developing some measures to monitor its impact. By contrast, UK hotels were, in general, less strategic in their use of SM. They were employing some of these tools exclusively to post information and to react to negative customer comments in review sites, and restore brand reputation.

The present study has shed light into the phenomenon of SM adoption in a hotel context, and has explored the topic in both a quantitative and qualitative way. The findings of the study facilitate an understanding of the most used tools, as well as the main advantages and challenges associated with its adoption. Consequently, we believe that our work makes a relevant contribution to the literature and offers relevant implications for managers, as they can gain valuable knowledge in order to properly implement these initiatives to better manage customer relationships.

There are a number of limitations of the present research, as well as areas for future research, that are worth mentioning. Regarding the limitations, first, it represents an exploratory study to address the topic of SM use in hotels, but no causal analysis has been performed. Second, the use of crosssectional data prevents us from examining the evolution in time of the phenomenon under study. Third, the use of managerial perceptions could be considered also as a limitation. Thus, only managers of hotels were asked to complete the questionnaire, but no information about employees and/or customer perceptions about SM adoption were used.

Finally, and considering that research into SM is still at an embryonic stage (Michaelidou et al., 2011), this study suggests the need for further research analyzing the topic in a confirmatory way and specifically focusing on the strategic challenges that SM implementation involves: how to integrate the use of these tools to their full potential, how to measure its results and how to carry out the cultural and organizational change needed for its success.

\section{References}

Baird, C. H. \& Parasnis, G. (2011). From social media to Social CRM. Strategy \& Leadership, 39 (5), 30-37.

Berthon, P.R., Pitt, L.F., Plangger, K. \& Shapiro, D. (2012). Marketing meets Web 2.0, social media, and creative consumers: Implications for international marketing strategy. Business Horizons, 55(3), 261-271.

Blal, I. \& Sturman, M.C. (2014). The Differential Effects of the Quality and Quantity of Online Reviews on Hotel Room Sales. Cornell Hospitality Quarterly (in press), doi: 10.1177/1938965514533419.

Bradley, A.J. \& McDonald, M. P. (2011). The Social Organization: How to Use Social Media to Tap the Collective Genius of Your Customers and Employees. Boston: Harvard Business Review Press.

Buhalis, D. \& Law, R. (2008). Progress in information technology and tourism management: 20 years on and 10 years after the Internet - The state of eTourism research. Tourism Management, 29(4), 609-623.

Cabiddu, F., De Carlo, M. \& Piccoli, G. (2014). Social media affordances: Enabling customer engagement. Annals of Tourism Research, 48, 175-192.

Chan, N. L. \& Guillet, B. D. (2011). Investigation of Social Media Marketing: How Does the Hotel Industry in Hong Kong Perform in Marketing on Social Media Websites?. Journal of Travel \& Tourism Marketing, 28(4), 345-368.

Escobar-Rodríguez, T. \& Carvajal-Trujillo, E. (2013). An evaluation of Spanish hotel websites: Informational vs. relational strategies. International Journal of Hospitality Management, 3, 228-239. 
Garín-Muñoz, T. \& Pérez-Amaral, T. (2011). Internet usage for travel and tourism: the case of Spain. Tourism Economics, 17(5), 1071-1085.

Gilbert, D. C., Powell-Perry, J. \& Widijoso, S. (1999). Approaches by hotels to the use of the Internet as a RM tool. Journal of Marketing Practis. Applied Marketing Science, 5(1), 21-38.

Google (2014). Worldwide data. Google Analytics (Q1, 2014).

Hansen, D. L., Shneiderman, B. \& Smith, M.A. (2011). Analysing Social Media Networks with NodeXL: Insights from a Connected World. Burlington: Morgan Kaufmann.

Haro de Rosario, A., Gálvez-Rodríguez, M.M. \& Caba-Pérez, M.C. (2013). Development of social media and web 2.0 in the top hotel chains. Tourism \& Management Studies, 9(1), 13-19.

Hsu, Y. L. (2012). Facebook as international eMarketing strategy of Taiwan hotels. International Journal of Hospitality Management, 31(3), 972-980.

IABD Spain (2014). V Estudio anual de Redes Sociales. Retrieved July 21, 2014, from: http://www.iabspain.net/redes-sociales/.

Jung, T. H., Ineson, E. M. \& Green, E. (2013). Online social networking: Relationship marketing in UK hotels. Journal of Marketing Management, 29, 3-4.

Kaplan, A.M. \& Haenlein, M. (2010). Users of the world, unite!. The challenges and opportunities of social media. Business Horizons, 53(1), 59-68.

Line, N. D. \& Runyan, R. C. (2012). Hospitality marketing research: recent trends and future directions. International Journal of Hospitality Management, 31(2), 477-488.

Llonch, J., Eusebio, R. \& Ambler, T. (2002). Measures of Marketing Success: A Comparison Between Spain and the UK. European Management Journal, 20(4), 414-422.

Mena, C., Adenso-Diaz, B. \& Yurt, O. (2011). The causes of food waste in the supplier-retailer interface: Evidences from the UK and Spain. Resources, Conservation and Recycling, 55(6), 648-658.

Miller, J. \& Glassner, B. (2004): The "inside" and the "outside": Finding realities in interviews. In D.Silverman (Ed.), Qualitative research: Theory, method and practice (págs. 125-139). London: Sage.

Michaelidou, N., Siamagka, N.T. \& Christodoulides, G. (2011). Usage, barriers and measurement of social media marketing: An exploratory investigation of small and medium B2B brand. Industrial Marketing Management, 40(7), 1153-1159.

Munar, A.M. \& Jacobsen, J.K.S. (2014). Motivations for sharing tourism experiences through social media. Tourism Management, 43, 46-54.

Neuhofer, B., Buhalis, D. \& Ladkin, A. (2012). Conceptualising technology enhanced destination experiences. Journal of Destination Marketing \& Management, 1, 36-46.
Noone, B.M., McGuire, K.A. \& Rohlfs, K.V. (2011). Social media meets hotel revenue management: Opportunities, issues and unanswered questions. Journal of Revenue and Pricing Management, 10(4), 293-305.

Orfila-Sintes, F., Crespí-Cladera, R. \& Martínez-Ros, E. (2005). Innovation Activity in the hotel industry: Evidence from Balearic Islands. Tourism Management, 26(6), 851-865.

Park, S. \& Allen, J. P. (2013). Responding to Online Reviews: Problem Solving and Engagement in Hotels. Cornell Hospitality Quarterly, 54(1), 64-73.

Sashi, C.M. (2012).Customer engagement, buyer-seller relationships, and social media. Management Decision, 50(2), 253-272.

Sigala, M. (2011). eCRM 2.0 applications and trends: The use and perceptions of Greek tourism firms of social networks and intelligence. Computers in Human Behavior, 27(2), 655-661.

Sigala, M. (2012). Exploiting Web 2.0 for New Service Development: Findings and Implications from the Greek Tourism Industry. International Journal of Tourism Research, 14(6), 551-566.

Silveira-Chaves, M., Gomes, R. \& Pedron, C. (2012). Analysing reviews in the Web 2.0: Small and medium hotels in Portugal. Tourism Management, 33(5), 1286-1287.

Smith, P.R. \& Zook, Z. (2011). Marketing Communications. London: Kogan Page Publishers.

TripBarometer (2014). TripBarometer April 2014: Global Edition. Retrieved July 18, 2014, from: http://www.tripadvisor.com/TripAdvisorInsights/n2200/tripbarometer -april-2014-global-edition.

Westphal, J. D. \& Fredickson, J. W. (2001). Who directs strategic change? Director experience, the selection of new CEOs, and change in corporate strategy. Strategic Management Journal, 22(12), 1113-1137.

Word Tourism Organization. (2013). Tourism Highlights, 2013 Edition. Retrieved November 17, 2013, from http://mkt.unwto.org/en/publication/unwto-tourism-highlights-2013edition.

Ye, Q., Law, R, Gu, B. \& Chen, W. (2011). The influence of usergenerated content on traveler behavior: An empirical investigation on the effects of e-word-of-mouth to hotel online bookings. Computers in Human Behavior, 27(2), 634-639.

\section{Article history:}

Submitted: 26.11 .2014

Received in revised form: 18.03.2015

Accepted: 19.03.2015 